\title{
Seaport network performance measurement in the context of global freight supply chains
}

\author{
Jasmine Siu Lee Lam, Ph.D., Assistant Professor \\ Nanyang Technological University, Singapore \\ Dong-Wook Song, Ph.D., Professor \\ Heriot-Watt University, United Kingdom
}

\begin{abstract}
A global distribution channel with a reliable freight transport system is essential in the contemporary world economy. Acting as trade facilitators, seaports are important players in the system. The study of the role of ports in supply chain management has recently drawn increasing attention from researchers and industry professionals alike. However, prior works mainly gathered the views from ports and terminals. To the authors' knowledge, no attempt by previous empirical studies has been made to cover the perspective from shippers and logistics providers, who are obviously taking a serious role in the process of global freight movements as major stakeholders. It becomes thus imperative to assess a port's supply chain orientation and performance from the perspective of the port users in the supply chain. Studying ports in the network context would be even more beneficial to capture the complexity needed to understand port performance and its interaction with various stakeholders. Drawing reference from multi-disciplinary fields, this paper aims to fill in the gap by developing a so-called unified framework for analysing port's integration in global freight supply chains including shipping line networks, hinterland and intermodal transport network, and even urban network. The framework embraces a wider group of stakeholders involved, for example, terminal operators, port authorities, shippers, shipping companies, inland transport providers, freight forwarders/logistics service providers, cities and other ports in the networks. A port that is a key node in these networks simultaneously would be able to create and sustain value for port stakeholders. Port authorities and operators can refer to the framework as their network performance indicators so as to obtain a better understanding of the various considerations in a port's network performance and to assist in positioning the port within the complex dynamics in the context of global freight supply chains. Finally, the framework developed in the paper can serve as a guide to empirical examinations of an emerging theme - a network-oriented performance by seaports along global freight supply chains - leading to various possible channels in future research.
\end{abstract}

Keywords: seaport; network performance; supply chain; sustainability; stakeholder

\section{INTRODUCTION}

A global distribution channel with a reliable transport system becomes ever more essential in the contemporary world economy, which is closely interlinked, for example, among manufacturers, consumers and assemblers. From a macroeconomic point of view, the increasing number of countries adopting market economies has brought about a change in how countries view the potential of international commerce and trade. The diversification and specialisation of markets, and the potential and impact of emerging or changing patterns of globalisation have added a new dimension to freight transport and affected the structure and operation of the transport industry as a whole (OECD, 2011). With globalisation and the increasing pressure to remain competitive, a country's capability to reduce transaction costs through the provision of adequate and efficient freight transport systems is more critical than ever. From a microeconomic perspective, on the other hand, due to competitive pressures brought by consolidation in the manufacturing sector, firms tend to produce in places where resources are less expensive. Finding sources in lowering production cost has led to a situation where companies spread their production units across continents. These developments in the world economy have been accelerated owing to factors like the importance of economies of scale, geographical expansion and trade liberalisation, which in turn lead to increasingly globalised enterprise activities. Consequently, the manufacturing industry in global supply chains becomes more dependent upon shipping and ports in inbound as well as outbound logistics.

Having acted as trade facilitators, seaports*) are important players in the freight transport system. The era of globalisation and global supply chain management (SCM) has led to the evolving roles of ports and port operators which are shaping

\footnotetext{
${ }^{*}$ ) Seaport or port will be used in an interchangeable manner throughout this paper.
} 
an emerging academic discipline. The critical nature of a seaport is a connection point. It is a platform linking sea and inland transportation, the local hinterland and overseas foreland, various shipping and transport service providers as well as trade and the urban system where the port is located. Drawing references from multiple disciplines, this paper aims to develop a so-called unified framework for analysing port's integration in global freight supply chains including shipping line networks, hinterland and intermodal transport network, and urban network. A port that is a key node in these networks simultaneously would be able to create and sustain value for port stakeholders. In this paper, sustainability is viewed from the overall performance perspective and sustainable value refers to the benefit brought to stakeholders which is strategic and not easily to be imitated (Ketchen et al., 2008). The framework ultimately aims to contribute to the research domain by devising an original and systematic reference to network performance measurement for the benefit of charting future research efforts and industry applications.

After the introduction, this article is organized as follows. A literature review is given in the next section, while the third section presents the research methodology. Conceptual development is then discussed in detail, followed by the section in which a hierarchical structure of port's network performance evaluation indicators is illustrated. The sixth section discusses the practical and research implications drawn from the conceptual framework. Finally, the concluding remarks are made.

\section{LITERATURE REVIEW}

The study of the role of ports in SCM has drawn increasing attention from researchers and industry professionals alike. Seaports have become a key node in supply chains and global distribution channels (Robinson, 2002). A study on European ports called for a change of mindset from "port-to-port" to "door-to-door" operations and management (Perez-Labajos and Blanco, 2004). Global terminal operators are increasingly aware of the trend that the supply chain is regarded as a total integrated system. Vertical integration strategies would help to extend the terminal operators' control over the chain, thus making them more attractive to be the chosen operator (De Souza et al., 2003). Paixao and Marlow (2003) claimed that ports have indeed become more integrated in supply chains. They introduced the logistics concepts of 'lean' and 'agile' operations as key indicators of port performance in supply chains, and suggested that a port's performance and competitiveness increasingly depend on logistics attributes in determining cost and responsiveness. Hall and Robbins (2007) and Mangan and Lalwani (2008) also stated that ports have become increasingly responsive to major customers' supply chains. It has been illustrated by some studies that concepts of supply chain when incorporated into port planning and management can enhance port performance (Carbone and Martino, 2003; Almotairi and Lumsden, 2009; Lam and Yap, 2011).

Scholarly work in this field is gradually emerging but still quite limited in terms of breath and depth. Particularly, empirical work on the integration of ports in the supply chain is relatively scant. Table 1 summarises those empirical studies on ports in the supply chain context. To critically assess the state of the literature on this topic in focus, those papers just mentioning ports' connection with the supply chain without fulfilling the objective to understand ports' role/ relationship/ integration with the supply chain are not included in table 1. Focusing on the role of ports in the automotive supply chain, Carbone and Martino (2003) conducted surveys with various operators in the port of Le Havre to analyse how they are involved in the supply chain. The study found that generally port competitiveness is increasingly dependent on external coordination and control of the whole supply chain. However, the authors admitted that the research findings cannot be generalisable as the work lacks wider field testing. In another attempt having claimed that ports are logistics centres playing a vital nodal role in the changing patterns of maritime and intermodal transport, Bichou and Gray (2004) suggested and tested a framework of port performance measurement from a logistics and supply chain management approach. It was found that the model is generally supported suggesting that there is a need to expand the scope of the inquiry beyond seaports to other supply chain members in order to investigate their perceptions and potential contribution to a shared management of international supply channels. Carbone and Gouvernal (2007) performed a survey with selected experts and confirmed the increasing awareness of the role of effective relationship management for a port's competitiveness.

In a recent work, Song and Panayides (2008) conducted a survey to collect the views from container port/terminal managers worldwide. Certain parameters of supply chain integration such as use of technology, value added services and user relationships are positively related to the parameters of port competitiveness. The authors suggested that these parameters form a basis for the exact attributes that contribute to port competitiveness in the supply chain. Panayides and Song (2008) extended the previous work by developing a measurement instrument that can be used by researchers to measure the extent to which a port or container terminal is supply chain oriented. Via a survey of container terminal operators in Europe and East Asia, the constructs were validated using confirmatory factor analysis. Tongzon et al. (2009) studied the port of Incheon as a case in point and measured the degree of its supply chain orientation based on the indicators developed by Panayides and Song (2008). The study found that ports or terminals in practice may not be supply chain oriented as theories predict. There is also a major gap on shipping companies' requirements perceived by port operators according to Woo et al. (2011). Based on a survey with various sectors in South Korea, port operators asserted that low price rather than high service quality is the most strongly required by shipping companies. But shipping companies indicated that service quality is the most important requirement on port performance in logistics environments.

Robinson (2002) suggested that ports are parts of a valuedriven chain system and it is important for the port and its service providers to offer sustainable value to its users against other competing value-driven chain systems. Freight moves only when shippers and customers derive value and competitive advantage. Port users including shipping companies, shippers, consignees and freight forwarders/ logistics service providers are the ones who perceive such value. However, except for Tongzon et al. (2009) and Woo et al. (2011), the prior works mainly gathered the views from ports and terminals. Tongzon et al. (2009)'s survey included container lines, yet it studied only the port of Incheon. As for Woo et al. (2011), shipping companies' view was also restricted to 13 responses from South Korea. To the authors' knowledge, no attempt has been made by previous empirical studies to cover the perspective from shippers and logistics providers in the topic of port's integration in the supply chain, who are obviously taking a serious role in the process of global freight movements. It becomes thus important to assess a port's supply chain orientation and performance from the perspective of the port users in the supply chain. According to Ketchen et al. (2008), best value 
Tab. 1. Summary of empirical studies on ports in the supply chain

\begin{tabular}{|c|c|c|c|c|}
\hline No. & References & Perspectives of & $\begin{array}{c}\text { Geographical } \\
\text { coverage }\end{array}$ & Major findings \\
\hline 1. & $\begin{array}{c}\text { Carbone } \\
\text { and Martino } \\
(2003)\end{array}$ & $\begin{array}{l}\text { Various port } \\
\text { operators }\end{array}$ & $\begin{array}{l}\text { Port of Le } \\
\text { Havre }\end{array}$ & $\begin{array}{l}\text { When a port has gained the status of a crossroad between the } \\
\text { production and distribution spheres, higher integration with the } \\
\text { port operators' major customers is called for }\end{array}$ \\
\hline 2. & $\begin{array}{l}\text { Bichou and } \\
\text { Gray (2004) }\end{array}$ & $\begin{array}{l}\text { Ports, } \\
\text { international } \\
\text { institutions and } \\
\text { experts }\end{array}$ & Global & $\begin{array}{l}\text { - Ports are logistics centres playing a vital nodal role in the changing } \\
\text { patterns of maritime and intermodal transport } \\
\text { - Supply chain approach in port performance measurement is } \\
\text { supported }\end{array}$ \\
\hline 3. & $\begin{array}{l}\text { Carbone and } \\
\text { Gouvernal } \\
(2007)\end{array}$ & $\begin{array}{l}\text { Experts largely } \\
\text { from the } \\
\text { maritime field }\end{array}$ & Global & $\begin{array}{l}\text { - A main global trend on maritime supply chain is the increasing } \\
\text { control of ports by international terminal operators } \\
\text { - Stable relationships with other actors in supply chain is a very } \\
\text { important factor in port competitiveness }\end{array}$ \\
\hline 4. & $\begin{array}{l}\text { Song and } \\
\text { Panayides } \\
(2008)\end{array}$ & $\begin{array}{l}\text { Container ports } \\
\text { and terminals }\end{array}$ & Global & $\begin{array}{l}\text { Value added services, use of technology and relationship with } \\
\text { shipping lines are positively related to port competitiveness }\end{array}$ \\
\hline 5. & $\begin{array}{l}\text { Panayides } \\
\text { and Song } \\
(2008)\end{array}$ & $\begin{array}{l}\text { Container } \\
\text { terminals }\end{array}$ & $\begin{array}{l}\text { Europe and } \\
\text { East Asia }\end{array}$ & $\begin{array}{l}\text { Validated constructs: (1) information and communication systems, } \\
\text { (2) value added services, (3) multimodal systems and operations, } \\
\text { (4) supply chain integration practices }\end{array}$ \\
\hline 6. & $\begin{array}{l}\text { Tongzon et } \\
\text { al. (2009) }\end{array}$ & $\begin{array}{l}\text { Container } \\
\text { terminals and } \\
\text { liners }\end{array}$ & Incheon & $\begin{array}{l}\text { There is a significant gap in perceptions between terminal } \\
\text { operators and shipping lines with the widest gap observed in the } \\
\text { provision of value-added services. }\end{array}$ \\
\hline 7. & $\begin{array}{l}\text { Woo et al. } \\
\quad(2011)\end{array}$ & $\begin{array}{l}\text { Port operators, } \\
\text { shipping } \\
\text { companies, } \\
\text { public sector } \\
\text { and academics }\end{array}$ & South Korea & $\begin{array}{l}\text { - Port operators assert that low price rather than high service quality } \\
\text { is the most strongly required by shipping companies. } \\
\text { - But shipping companies indicate that service quality is the most } \\
\text { important on requirement port performance. }\end{array}$ \\
\hline
\end{tabular}

supply chains go beyond traditional logistics requirements by stressing a holistic logistical value proposition which finds the ideal balance of the key competitive priorities, namely speed, quality, cost, and flexibility. Hence, for ports to contribute to the best value approach, they should also find the right balance of these key competitive priorities. It will be interesting to investigate what the right balance is. Furthermore, mainly inland transport connectivity was included as one of the constructs in existing measurement instruments. It appears that the prior studies neglected ports' seaward connectivity with other ports. Without assessing port-to-port connectivity, the performance measures only cover part of the supply chain, i.e. between port and hinterland, but not from the point of origin to the point of destination.

\section{RESEARCH METHODOLOGY}

Noting the various gaps in the literature, this study addresses the various issues by developing a comprehensive conceptual framework based on literature research, observation from the port industry and six semi-structured interviews conducted with maritime industry professionals and academic. Drawing reference from multiple disciplines, a detailed literature review has been performed to broaden the perspective on how to investigate into port research. Also, various sources such as trade journals, market reports, databases and credible internet references were consulted for collecting data and information. Six in-depth interviews were carried out from mid 2011 to mid 2012 to gain more insights from the industry practitioners and experts. Five interviews were targeted at the management personnel of a shipper, a logistics service provider, a terminal operator, a shipping line and a maritime consulting firm respectively. As such, both port operator's and port user's views were represented, whereas the professional from the maritime consulting firm offered a neutral perspective since it is a third party which is neither a port operator nor a port user. As the research topic is in the context of global freight supply chains, the sample was selected from Fairplay's World Shipping Directory to include those international entities serving a wide coverage of the global market. Then a management executive in charge of supply chain solutions from the Asia headquarter or regional offices in each company was randomly selected from the sample companies and approached for an interview. To include the viewpoint from the scientific research community, an academic in the maritime field was also interviewed. The six interviewees have given information and opinion on the proposed framework and performance indicators in analysing port's integration with various networks which will be discussed in the next sections. The research design is to achieve the benefits from triangulation, whereby multiple data collection methods can mitigate biases and lead to stronger substantiation of research constructs (Eisenhardt, 1989). This study utilizes qualitative approach involving compilation, summary, comparison, classification and analysis of the data, information and opinion.

\section{CONCEPTUAL DEVELOPMENT}

\section{Port's integration in supply chain network}

The literature emphasised the importance of logistics integration into marketing channels in supply chains (Langley 
and Holcomb, 1992; Alvarado and Kotzab, 2001). In the new paradigm seeing port as an element in supply chains, ports play a role in this logistics integration in delivering a value to their main customers (e.g., shipping companies), then to shippers and consignees, and accessorily to transport and logistics service providers (Robinson, 2002). These players do not choose a port per se, but a supply chain comprising a bundle of logistics services and a pathway to markets (Magala and Sammons, 2008). The rising demand from global customers in the competitive market creates a need for fourth generation ports, which are nodal points in supply chains and integrate with other supply chain members to form networks (UNCTAD, 1999). Lean and agile logistics would improve on efficiency and enhance integration of ports in supply chains to meet today's market requirements (Paixao and Marlow, 2003; Pettit and Beresford, 2009). This development supports the demand from global production networks whose interconnected nodes and links extend spatially across national boundaries and, in so doing, integrate parts of disparate national and subnational territories (Coe et al., 2008). Paixao and Marlow (2003), Bichou and Gray (2004) and Panayides and Song (2008) all have observed that ports are increasingly integrated in supply chains and the port performance evaluation framework should be built from the supply chain perspective. When different supply chains pass through the same seaport, the port authority could use benchmarking to identify the proper management model for the specific port and could utilize this approach to make decision about infrastructure investments and related hinterland connections (Carbone and Martino, 2003). The idea can be extended to include terminal operator for assessing port operations and management.

\section{Port's integration in hinterland/intermodal transport network}

As an interface between the water side and the shore, ports should be well connected with maritime transport on one hand and inland transport on the other hand. We firstly discuss inland transport connections. Hinterland is the backyard of cargo source for gateway ports. Ports strive to capture and expand their hinterland to the best they can and thus intensify landbased port competition (Starr and Slack, 1995). In the process, the emergence of inland ports, also known as dry ports, from the hinterland and regional development perspective can be explained by "port regionalization" (Notteboom and Rodrigue, 2005). Its characteristic is port functional integration and even joint development with hinterland logistics platforms in order to shape a regional transportation network to meet requirements from global freight distribution channels and chains. There is higher demand for port expansion due to increasing port traffic. However, local opposite voices owing to environment concerns present a paradoxical phenomenon in port development. Inland ports and other logistics platforms together with gateway seaports would form regional transportation network to mitigate this acute problem and achieve another optimised pattern of port expansion and externalization. The development of inland ports and freight corridors could be considered as port regionalization process involving integration between maritime and inland freight transportation (Notteboom and Rodrigue, 2005; Roso, 2007; Roso et al, 2009). The degree to which a port is integrated in the hinterland network is increasingly regarded as strategic and contributes to sustainability, thus represents an indicator of port performance.

\section{Port's integration in liner shipping network}

This section then discusses maritime connections. Ports having good geographical location along with major artery of maritime traffic are naturally advantageous. Singapore, Port Klang and Tanjung Pelepas situated along the Straits of Malacca and the ports of Hong Kong and Shenzhen as the gateway of South China, one of the world's largest manufacturing bases, are good examples. Ports are strategically important to shipping companies' and shippers' system (Hayuth and Fleming, 1994). The presence, extent and development of port competition and relationships can be determined by the levels and changes of shipping lines and slot capacity connected (Lam and Yap, 2011). Port centrality in liner shipping networks is a key determinant of port hierarchy (Ducruet et al., 2010; Doshi et al., 2012). Overall, seaward connectivity in terms of shipping services deployed is a performance indicator to analyse ports (as nodes) and routes and shipping lines (as links) that are embedded within the maritime supply chain (Lam, 2011). However, liner networks are ephemeral and dynamic since container shipping lines periodically restructure their networks to adjust to the demands from the market. Thus port connectivity is bound to change as well (Lam and Yap, 2011). Ports should keep themselves abreast of such dynamics and be proactive in attempting to sustain their position as a key node.

\section{Port's integration in urban network}

Ports are economic springboards for city and regional development. This has been sufficiently established by the fact that major cities and industries have developed in coastal locations to take advantage of maritime trade. In addition to facilitating trade and industries, ports contribute to economic development due to multiplier effects of port activities (Suykens, 1989). A port city is a hub in dense networks of maritime connections through which people, goods, ideas and meanings flow. Global port cities are powerful manifestations of global flows and trans-national integration (Driessen, 2005; Lee et al., 2008). A port city also plays key political and social roles in influencing its hinterland, including creating employment opportunities for residents. For example, Singapore is a global city-state with its port driving the international manufacturing, transport, communication and financial hub status (Tan, 2007; Lee et. al., 2008). Nevertheless, optimising land use in view of increasingly stringent requirements from port users, competition for space from other sectors in the economy and increasing environmental concerns present concerns on port city development. Conflicts between the port and the city also exist due to urban traffic congestion and waterfront redevelopment (Hayuth, 2007). For instance, how to reconfigure Hamburg as a port city is a challenge (Grossmann, 2008). Port city research has attracted attention from geographers, economists, sociologists and historians (Tan, 2007). Thus the topic is multidisciplinary, though it is reckoned that geography is a major direction in the literature so far. Hence, in terms of city and regional development, ports are important nodal points in urban networks. Ports should coordinate well with the city where it is located and generate sustainable values to it. This represents another indicator of port performance.

\section{The concept of node and network}

As revealed from the above discussion, a common concept which is important across various disciplines is centrality of a node and its integration with a comprehensive network. In 
terms of spatial network in geography, centrality measures the level of concentration of a node. Intermediacy is to describe the closeness between origins and destinations (Fleming and Hayuth, 1994). These concepts have been widely applied to transportation and urban studies. In the field of strategic management, strategic networks and inter-firm collaboration have received considerable attention from researchers. Centrality measures the ability to access (or control) resources through direct and indirect links. Network centrality at the interpersonal (Brajkovich, 1994) and inter-organizational levels (Birley, 1985; Larson and Starr, 1993; Partanen and Möller, 2011) were studied. In sociology, particularly social network analysis, node centrality refers to the importance of a node due to its structural position in the network as a whole. A type of centrality is closeness, which is the sum of distances to or from all other nodes (Freeman, 1979). Another type of centrality is betweenness, which is a measure of the extent that a node lies along many shortest paths between pairs of others (Freeman, 1977). Social network analysis in the context of logistics and supply chain management is emerging (Carter et al., 2007; Borgatti and Li, 2009; Kim et al., 2011). In fact, there has been increasing interest in conducting supply chain research adopting a network perspective rather than merely a linear chain perspective.

The importance of port and terminal integration in supply chains has already been established in the literature. While studying ports from the supply chain perspective would be helpful, studying ports in the network context would be even more beneficial to capture the complexity needed to understand port's performance and its interaction with various stakeholders. Furthermore, we propose a holistic approach which considers not only one type of network, but a set of networks simultaneously, namely supply chain network, liner shipping network, hinterland/intermodal transport network and urban network, as illustrated in figure 1's unified framework. No matter whether we see port as a spatial, social or commercial entity, port's connectedness and integration with the networks are crucial qualities. There would also be trade-offs, conflicts and tensions that arise from trying to fulfill the needs of the four different stakeholder groups (De Langen, 2007; Coe et al., 2008). A port acting as a key node in these networks simultaneously and balancing the stakeholder groups' interests would be able to create and sustain value for port stakeholders including port users, hence the port possesses a competitive advantage which is difficult for rivals to replicate. The combined outcome is considered similar to the idea of agglomeration effect from development economics perspective put forth by Fujita and Mori (1996) who studied port cities. Our research approach is also able to unify the related research topics from various disciplines as discussed above, which is an original contribution.

\section{SEAPORT'S NETWORK PERFORMANCE INDICATORS}

This paper attempts to develop a framework for analysing a port's integration in various networks as discussed above. The framework is intended to be applicable to all container seaports. As such, based on Figure 1, we further develop a list of performance indicators and a systematic approach for the evaluation. The study proposes a hierarchical structure which categorises the performance indicators in three layers. The first layer is called evaluation determinants, which include three fundamental and encompassing indicators considering overall port performance - quality, timeliness and cost - with reference to logistics and supply chain performance analysis conducted by Ketchen et al. (2008) and Garcia et al. (2012) as well as other scholars. Explanation on the network performance indicators will be given below.

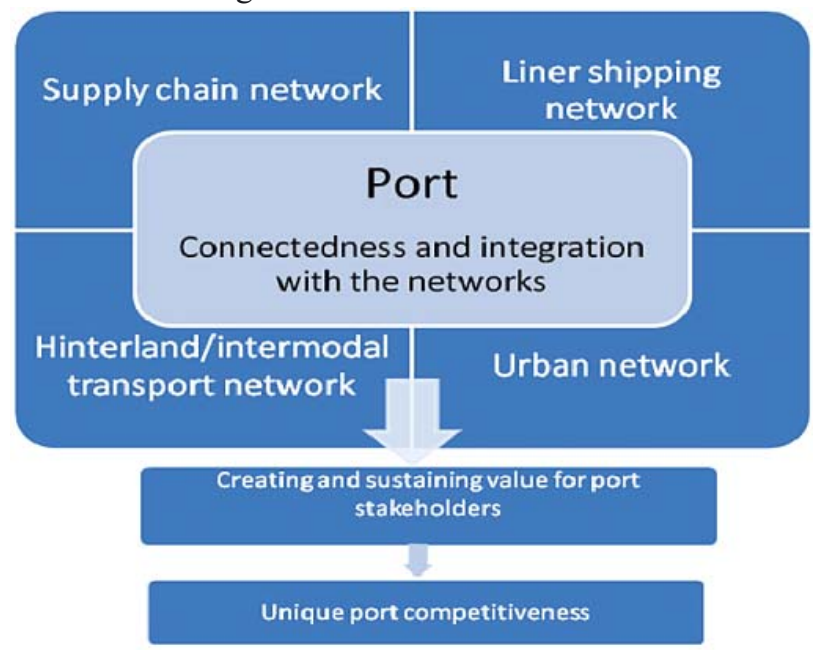

Fig. 1. A unified framework for a port's integration in associated networks. Source: Drawn by the authors

Quality refers to the standard of the assets, service, process, planning, staff, shipment, documentation, safety, security, management and control in connection to a port's networks. It affects the productivity, effectiveness and reliability of the port's operations. Quality has become a major concern for shippers, and the primary value sought by many shippers has shifted from price to quality service performance (Lagoudis et al., 2006). From the total quality management's point of view, high quality operations and service would result in lower costs for users (Braglia and Petroni, 2000). Timeliness refers to time-related performance in terms of transit time, frequency, responsiveness, reliability and agility. Shipping is a vital component in global supply chain management, and at the same time, shipping appears a weak link due to its slow speed and low reliability (Saldanha et al., 2009). Shipping also faces more demanding customers and greater challenges as supply chains become longer and more complex. Time-related attributes are increasingly important due to the prevalence of just-in-time practice and are often found to be significant for shipping and ports (Cullinane et al. 2002; Carbone and Martino, 2003). Cost is another important performance indicator. It represents a total cost covering direct cost, indirect cost, logistics cost, shipment cost, ordering cost, fluctuation of cost and cost reduction performance. In general, suppliers offering cost effective solutions are highly valued (Chan and Kumar, 2007). Cost competitiveness can be translated to price attractiveness and lower user costs and thus is a crucial contributor to a port's competitive advantage (Lam and Yap, 2006; Yeo et al., 2011).

Thereafter, the second layer of the hierarchical structure is known as evaluation dimensions. As derived from the literature of various disciplines, port's connectedness and integration with other network members can be classified as three types: functional, information and communication, relationship. The dimensions specify the aspects of the upper-level evaluation determinants. First, functional integration is fundamental especially when physical movement of cargoes is concerned. This includes infrastructure and route connections among the various nodes in the intermodal transport network (Parola and Sciomachen, 2005). Smart management of container logistics system is also crucial for sustainable development, using systematic support (software) to offset the limitations in equipment (hardware) (Notteboom and Rodrigue, 2008). 
Building upon the physical network and system, service offerings such as value-added service and compatibility with the port users/stakeholders also determine the level of functional integration. Second, information flow is a major form of flow in supply chain management, which emphasizes the overall and long-term benefit of all parties in the chain through co-operation and information sharing (Srinivasan et al., 1994). Inter-organizational information system is one of the means to enhance information flow (Lu et al., 2006). Other than technology, the quality of communication between the organisations is also based on personnel's competency (Paulraj, 2008). Third, effective inter-organizational relationships are important to SCM. Closer and long-term relationships based on trust within the supply chain would contribute to higher supply chain performance and better financial returns (Dyer and Singh, 1998; Fynes et al., 2005). There is also a positive link between a firm's relational orientation and technological innovation (Hakansson and Ford, 2002). Wilding and Humphries (2006) demonstrated the importance of cooperation, coordination and collaboration in collaborative supply chain relationships. Hence, though relatively intangible, the relational dimension is crucial for port's network performance.

Tab. 2. Hierarchical structure of a port's network performance evaluation

\begin{tabular}{|c|c|}
\hline Layers & Performance indicators \\
\hline $\begin{array}{c}\text { 1: Evaluation } \\
\text { determinants }\end{array}$ & Quality, timeliness, cost \\
\hline $\begin{array}{c}\text { 2: Evaluation } \\
\text { dimensions }\end{array}$ & $\begin{array}{c}\text { Functional, information and } \\
\text { communication, relationship }\end{array}$ \\
\hline $\begin{array}{c}\text { 3: Evaluation } \\
\text { elements }\end{array}$ & $\begin{array}{c}\text { Shipping companies, other seaports, } \\
\text { customs, inland transport corridors, freight } \\
\text { forwarders/ logistics service providers, } \\
\text { inland ports, shippers/ consignees and the } \\
\text { city where a certain port is located }\end{array}$ \\
\hline
\end{tabular}

To further specify port's network performance, the thirdlayer indicators contain eight evaluation elements based on the networks identified above which are shown in figure 1 . The elements are shipping companies, other seaports, customs, inland transport corridors, freight forwarders/ logistics service providers, inland ports, shippers/ consignees and the city where a certain port is located. Shipping companies are port's direct customers and have the closest relationship with a seaport's maritime connectivity. This relates to a seaport's connection with other seaports as these shipping companies operate the shipping routes calling at and linking with a set of ports. Considering trade facilitation, customs is included as an element since it functions in ports for import and export activities. Port's integration in hinterland/intermodal transport network is another important aspect. Inland transport corridors are the links connected between the port and the hinterland, inland/dry ports are the nodes in the network, while freight forwarders/ logistics service providers are the operators. Finally, considering the urban network, how well a port is coordinated with its city should be included as an element. Altogether, these eight elements represent the nodes in various networks, port users as well as port stakeholders that formulate a port's network contents. Table 2 summarises the port's network performance evaluation indicators.

\section{PRACTICAL AND RESEARCH IMPLICATIONS}

This study makes a meaningful contribution to the existing literature by examining the topic of port's supply chain orientation and performance from the perspective of port users in the supply chain. An even more encompassing approach, which has yet been explored in the literature, is presented as a platform to investigate the subject from the wider perspectives of stakeholders engaged in the port businesses.

The concept of centrality for measuring the network performance of a node as discussed previously has been substantially extended in this research. The comprehensiveness of a port's network is specified by the eight evaluation elements. A port's integration level with these elements can be measured by three determinants from the angle of three dimensions. Thus the concepts of closeness and betweenness in centrality are embraced by our framework in terms of the quality measure in connectedness. In addition to spatial and social distances, a number of new considerations including process, planning, time, cost and information are incorporated into this multifaceted framework. In future, measuring instrument can be employed to analyse the conflicts and interrelationships among the various network performance evaluation indicators of a port.

The framework for port's network performance evaluation has proposed a hierarchical structure in organising the performance indicators. Port authorities and port operators can refer to the framework in order to obtain a better understanding of the various considerations in a port's network performance and the complex dynamics within the context of global freight supply chains. This reference could assist them to better monitor and assess the port's connectedness and integration with its associated networks, devise a new strategy for improvement, and work towards sustainable values to port users and stakeholders in the long term.

\section{CONCLUDING REMARKS}

This paper has provided a new insight into the framework for analysing port's integration in global freight supply chains having shipping line networks, hinterland and intermodal transport network, and urban network in mind. The framework embraces a wider group of stakeholders involved, for example, terminal operators, port authorities, shippers, shipping companies, inland transport providers, freight forwarders/ logistics service providers, cities and other ports in the networks. This inclusion of extended stakeholders reflects the sophisticated and evolving role played by ports in practice. The study has also unified the related research topics from various disciplines in network performance and thereby creates a new perspective into a multi-disciplinary subject matter.

As an exploratory study in analysing port's network performance within the context of global freight supply chain, this study has achieved the stated objectives. This paper, however, has a research limitation; that is, just a small number of interviews with industry professionals and academic were conducted as a pilot test for enhancing practicability and validity. The external validity of our proposed framework needs to be empirically tested with a much larger sample via survey as a potential method for further research. As demonstrated throughout the paper, the proposed framework has been thoroughly formulated through a comprehensive literature review and secondary research. Hence, collecting primary information and opinion from the maritime industry is regarded as a supplement in this stage of the research process.

As for other research areas that can be pursued in the future, a correlation analysis, for example, between a port's network performance and cargo throughput, is helpful in deepening our understanding on the research topic. Furthermore, case studies with reference to the framework and network performance 
indicators in question would be highly valuable for assessing and comparing the network performance of a port concerned. The research approach will be applicable to any container seaports in the world, regardless of port size and geographical location. A benchmarking study can be conducted for the benefit of identifying the port industry's best practices. As a whole, this line of study offers a theoretical exploration and specific performance indictors on a critical and topical research field, which could be extendable for an empirical examination.

\section{Acknowledgements}

The authors are grateful to five anonymous reviewers for their constructive and refreshing comments and Professor $\mathrm{S}$. Ganji, an editor of this special issue, for his encouragement and coordination throughout the whole process. This study is partially supported by Singapore Ministry of Education AcRF project NTU ref: RF20/10.

\section{References}

1. Almotairi, B. and Lumsden, K. (2009), Port logistics platform integration in supply chain management, International Journal of Shipping and Transport Logistics, 1(2), 194-210.

2. Alvarado, U.Y. and Kotzab, H. (2001), Supply chain management: the integration of logistics in marketing, Industrial Marketing Management, 30(2), 183-198

3. Bichou, K. and Gray, R. (2004), A logistics and supply chain management approach to port performance measurement, Maritime Policy and Management, 31(1), 47-67.

4. Birley, S. (1985), The role of networks in the entrepreneurial process, Journal of Business Venturing, 1(1), 107-117.

5. Borgatti, S.P. and Li, X. (2009), On social network analysis in a supply chain context, Journal of Supply Chain Management, 45(2), 5-22.

6. Braglia, M. and Petroni, A. (2000), A quality assurance-oriented methodology for handling trade-offs in supplier selection, International Journal of Physical Distribution and Logistics Management, 30(2), 96-111.

7. Brajkovich, L.F. (1994), Sources of social structure in a start-up organization: work networks, work activities, and job status, Social Networks, 16(3), 191-212

8. Carbone, V. and Martino, M. (2003), The changing role of ports in supply chain management: an empirical analysis, Maritime Policy and Management, 30(4), 305-320.

9. Carbone, V. and Gouvernal, E. (2007), Supply chain and supply chain management: appropriate concepts for maritime studies. In Wang, J., Olivier, D., Notteboom, T. and Slack, B. (Eds.) Ports, Cities and Global Supply Chains, England: Ashgate, 1126.

10.Carter, C.R., Ellram, L.M. and Tate, W.L. (2007), The Use of Social Network Analysis in Logistics Research, Journal of Business Logistics, 28(1), 137-168.

11.Chan, F.T.S. and Kumar, N. (2007), Global supplier development considering risk factors using fuzzy extended AHP-based approach. OMEGA - International Journal of Management Science, 35(4), 417-431.

12.Coe, N.M., Dicken, P. and Hess, M. (2008), Global production networks: realizing the potential, Journal of Economic Geography, 8, 271-295.

13.Cullinane, K., Ping, J. and Wang, T.-F. (2002), A multiobjective programming approach to the optimization of China's international container transport network, International Journal of Transport Economics, 29, 181-99.

14.De Souza, G.A., Beresford, A.K.C., Pettit, S.J. (2003), Liner shipping companies and terminal operators: internationalization or globalization? Maritime Economics and Logistics, 5(4), 393-412.

15.De Langen, P,W. (2007), Stakeholders, conflicting interests and governance in port clusters, Research in Transportation Economics, 17, 457-478.
16.Doshi, D., Malhotra, B., Bressan, S. and Lam, J.S.L. (2012), Mining maritime schedules for analyzing global shipping networks, International Journal of Business Intelligence and Data Mining, in press.

17.Driessen, H. (2005), Mediterranean port cities: cosmopolitanism reconsidered, History and Anthropology, 16(1), 129-141.

18.Ducruet, C., Lee, S.W. and Ng, A.K.Y. (2010), Centrality and vulnerability in liner shipping networks: revisiting the Northeast Asian port hierarchy, Maritime Policy and Management, 37(1), $17-36$.

19.Dyer, J.H. and Singh, H. (1998), The relational view: cooperative strategy and sources of inter-organisational competitive advantage, Academy of Management Review, 23, 660-679.

20.Eisenhardt, K.M. (1989). Building theories from case study research, Academy of Management Review, 14(4), 532-550

21.Fleming, D. and Hayuth, Y. (1994), Spatial characteristics of transportation hubs: centrality and intermediacy, Journal of Transport Geography, 2(1), 3-18.

22.Freeman, L.C. (1977), A set of measures of centrality based on betweenness, Sociometry, 40(1), 35-41.

23.Freeman, L.C. (1979), Centrality in social networks: conceptual clarification, Social Networks, 1, 215-239.

24.Fujita, M. and Mori, T. (1996), The role of ports in the making of major cities: Self-agglomeration and hub-effect, Journal of Development Economics, 49, 93-120.

25.Fynes, B., Voss, C., de Burca, S. (2005), The impact of supply chain relationship quality on quality performance, International Journal of Production Economics, 96, 339-354.

26.Garcia, F.A., Marchetta, M.G., Camargom, M., Morel, L. and Forradellas, R.Q. (2012), A framework for measuring logistics performance in the wine industry, International Journal of Production Economics, 135, 284-298.

27.Grossmann, I. (2008), Perspectives for Hamburg as a port city in the context of a changing global environment, Geoforum, 39, 2062-2072.

28.Hakansson, H. and Ford, D. (2002), How should companies interact in business networks. Journal of Business Research, 55, 133-139.

29. Hall, P.V. and Robbins, G. (2007), Which link, in which chain? Inserting Durban into global automotive supply chains, In Wang, J., Olivier, D., Notteboom, T. and Slack, B. (Eds.) Ports, Cities and Global Supply Chains, England: Ashgate, 221231

30.Hayuth, Y. (2007), Globalisation and the port-urban interface: conflicts and opportunities, In Wang, J., Olivier, D., Notteboom, T. and Slack, B. (Eds.) Ports, Cities and Global Supply Chains, England: Ashgate,141-156.

31.Hayuth, Y. and Fleming, D.K. (1994), Concepts of strategic commercial location: the case of container ports, Maritime Policy and Management, 21(3), 187-193.

32.Ketchen, D. J. Jr., Rebarick, W., Hult, G.T.M. and Meyer, D. (2008), Best value supply chains: A key competitive weapon for the 21st century, Business Horizons, 51, 235-243.

33.Lagoudis, I. N., Lalwani, C.S. and Naim, M.M. (2006), Ranking of factors contributing to higher performance in the ocean transportation industry: a multi-attribute utility theory approach, Maritime Policy and Management, 33, 345 - 369.

34.Lam, J.S.L. (2011), Patterns of maritime supply chains: slot capacity analysis, Journal of Transport Geography, 19(2), 366374.

35.Lam, J.S.L. and Yap, W.Y. (2006), A measurement and comparison of cost competitiveness of container ports in Southeast Asia, Transportation, 33(6), 641-654.

36.Lam, J.S.L. and Yap, W.Y. (2011), Dynamics of liner shipping network and port connectivity in supply chain systems: analysis on East Asia, Journal of Transport Geography, 19(6), 12721281.

37.Langley, C.J. and Holcomb, M.C. (1992), Creating logistics customer value, Journal of Business Logistics, 13(2), 1-27

38.Larson, A. and Starr, J.A. (1993), A network model of organization formation, Entrepreneurship: Theory and Practice, $17,35-46$. 
39.Lee, S.W., Song D.W. and Ducruet, C. (2008), A tale of Asia's world ports: the spatial evolution in global hub port cities, Geoforum, 39, 372-385.

40.Lu, X.H., Huang, L.H. and Heng, M.S.H. (2006), Critical success factors of inter-organizational information systems: A case study of Cisco and Xiao Tong in China, Information and Management, 43(3), 395-408.

41.Magala, M. and Sammons, A. (2008), A new approach to port choice modelling, Maritime Economics and Logistics, 10(1/2), 9-34.

42.Mangan, J. and Lalwani, C. (2008), Port-centric logistics, International Journal of Logistics Management, 19(1), 29-41.

43.Notteboom, T. E. and Rodrigue, J.-P. (2005), Port Regionalization: Towards A New Phase in Port Development, Maritime Policy and Management, 32(3), 297-313.

44.Notteboom, T.E. and Rodrigue, J.-P. (2008), Containerisation, Box Logistics and Global Supply Chains: The Integration of Ports and Liner Shipping Networks. Maritime Economics and Logistics, 10(1-2), 152-174.

45. Organisation for Economic Cooperation and Development (2010), Trends in the Transport Sector 2011, OECD Publishing.

46.Paixao, A. C., and Marlow, P. B. (2003), Fourth generation ports- a question of agility? International Journal of Physical Distribution and Logistics Management, 33(4), 355-376.

47.Panayides, P.M. and Song, D.-W. (2008), Evaluating the integration of seaport container terminals in supply chains, International Journal of Physical Distribution and Logistics Management, 38(7), 562-584.

48.Parola, F. \& Sciomachen, A. (2005), Intermodal Container Flows in A Port System Network: Analysis of Possible Growths Via Simulation Models, International Journal of Production Economics, 97(1), 75-88.

49.Partanen, J. and Möller, K. (2011), How to build a strategic network: A practitioner-oriented process model for the ICT sector, Industrial Marketing Management, doi:10.1016/ j.indmarman.2011.05.002.

50.Paulraj, A., Lado, A.A. and Chen, I.J. (2008), Interorganizational communication as a relational competency: Antecedents and performance outcomes in collaborative buyersupplier relationships, Journal of Operations Management, 26(1), 45-64.

51.Pettit, S. J., and Beresford, A. K. C. (2009), Port development: from gateways to logistics hubs, Maritime Policy and Management, 36(3), 253-267.

52.Perez-Labajos, C. and Blanco, B., (2004), Competitive policies for commercial sea ports in the EU. Marine Policy, 28(6), 553556.

53.Robinson, R. (2002), Ports as elements in value-driven chain systems: the new paradigm, Maritime Policy and Management, 29, 241-255.

54.Roso, V. (2007), Evaluation of the dry port concept from an environmental perspective: A note, Transportation Research Part D, 12, 523-527.

55.Roso, V., Woxenius, J. and Lumsden, K. (2009), The Dry Port Concept: Connecting Container Seaports with the Hinterland, Journal of Transport Geography, 17(5), 338-345.
56.Saldanha, J.P., Tyworth, J.E., Swan, P.F. and Russell, D.M. (2009), Cutting logistics costs with ocean carrier selection, Journal of Business Logistics, 30(2), 175-195.

57.Song, D.-W. and Panayides, P.M. (2008), Global supply chain and port/terminal: integration and competitiveness, Maritime Policy and Management, 35(1), 73-87.

58.Srinivasan, K., Kekre, S., Mukhopadhyay, T. (1994), Impact of electronic data interchange technology on JIT shipments, Management Science, 40, 1291-1304.

59.Starr, J.T. and Slack, B. (1995). Ports As Gateways: A Traditional Concept Revisited. Proceeding of the 5th Conference International Villes et Ports, Dakar, 89-96.

60.Suykens, F. (1989), The city and its port: an economic appraisal, Geoforum, 20(4), 437-445.

61.Tan, T.Y. (2007), Port cities and hinterlands: A comparative study of Singapore and Calcutta, Political Geography, 26, 851865.

62.Tongzon, J. Chang, Y.T. and Lee, S.Y. (2009), How supply chain oriented is the port sector? International Journal of Production Economics, 122, 21-34.

63.UNCTAD, (1999). The fourth generation port. UNCTAD Ports Newsletter 19, 9-12.

64.Wilding, R. and Humphries, A.S. (2006) Understanding collaborative supply chain relationships through the application of the Williamson organizational failure framework, International Journal of Physical Distribution and Logistics Management, 36( 4), 309-329.

65.Woo, S.H., Pettit, S. and Beresford, A.K.C. (2011) Port evolution and performance in changing logistics environments, Maritime Economics and Logistics, 13(3), 250-277.

66. Yeo, G.T., Roe, M. and Dinwoodie, J. (2011) Measuring the competitiveness of container ports: logisticians' perspectives, European Journal of Marketing, 45(3), 455 - 470.

\section{CONTACT WITH THE AUTHORS}

Jasmine Siu Lee Lam*, Ph.D., Assistant Professor Division of Infrastructure Systems and Maritime Studies

School of Civil and Environmental Engineering

Nanyang Technological University Singapore 639798

e-mail: sllam@ntu.edu.sg tel.: +6567905276

Dong-Wook Song, Ph.D., Professor

Logistics Research Centre

Heriot-Watt University

Edinburgh EH14 4AS

United Kingdom

e-mail: D.Song@hw.ac.uk tel.: +441314518206

* Corresponding author 